IJMS 20 (1), 77-108 (2013)

\title{
THE EFFECT OF CHINA AND THE FACTORS AFFECTING FOREIGN DIRECT INVESTMENTS IN ASEAN COUNTRIES
}

\author{
KOY PEI WEN \\ MOHAMED HISHAM YAHYA \\ ROSLINDA RAHMAN \\ Faculty of Economics and Management \\ Universiti Putra Malaysia \\ ABDUL RAZAK ABDUL HADI \\ Universiti Kuala Lumpur Business School \\ Universiti Kuala Lumpur
}

\begin{abstract}
Foreign direct investment (FDI) plays an important role in bolstering economic growth. It acts as a pillar in supporting the industrialization and economic development of countries. The objectives of this study are to: (a) Recognise factors affecting FDI in countries in the Association of Southeast Asian Nations (ASEAN) region and (b) examine the effect of China's entry into the World Trade Organisation (WTO) on the FDI in ASEAN countries. The Vector Autoregressive method (VAR) was applied to establish the factors that had significant impacts on FDI inflows over the period 1980-2010 for these countries. Apart from the conventional variables, such as market size, labour cost, interest rates, exchanges rates, corporate tax rates, and degree of openness, this study incorporates another variable, that is, the event of China joining the WTO. This is to determine whether the entry of China into WTO had any impact on FDI in the ASEAN region. The result reveals that, firstly, only market size is not a significant factor in determining the FDI inflows for all the ASEAN countries being studied (i.e. Indonesia, Malaysia, Philippines, Singapore and, Thailand). Secondly, most of the ASEAN member countries' FDI are influenced by China's entry into WTO in 2001.
\end{abstract}

Keywords: China, ASEAN, WTO, VAR, Foreign direct investment.

\section{Introduction}

Foreign direct investment (FDI) is a physical investment made by a company in one country into another country in the form of direct 
investment, direct acquisition of a foreign company, investment in strategic alliance or joint venture with a local firm. It brings about the benefits of providing advance technology spill over, a new source of capital inflows, products and process into the host countries. In addition, the specialized knowledge and the managerial expertise of the foreign firm can be widely transferred into the host country. Foreign direct investment has fluctuated over time in response to the changes in the investment environment. According to the International Finance Corporation (IFC), the trend of FDI has reflected the changes in industrial and development policies, from import substitution in the 1950s and 1960s, resource based-led development in the 1970s, to structural reforms and export orientation in the 1980s and 1990s.

Foreign direct investment plays a key role in the economic development of Southeast Asia. This, especially, holds true for the original five core members of the Association of Southeast Asian Nations-Indonesia, Malaysia, Philippines, Singapore and Thailand (ASEAN-5).This geo-economic grouping underwent a techno-industrial revolution prompted by FDI of multinational companies (MNCs), mainly from Japan, the US, and Europe. The economies of ASEAN-5 experienced 8 per cent to 12 per cent GDP growth rate prior to the Asian financial crisis. The worldwide economic analysts referred to it as miracles for the region. After the 1997 and 1998 financial crisis, ASEAN-5 faced the problem of a radical decline in the percentage of FDI flows into Southeast Asia, especially in countries such as Indonesia and the Philippines (Freeman \& Bartels, 2004). This unexpected crisis led to considerable negative influence in the level of inward FDI into ASEAN-5 which resulted in further dampening the weak economy of the countries in this group. The establishment of foreign firms will also increase the demand for labour in the host countries. Foreign direct investment increases the employment rate of the host countries and increase the wage rate of the country as a result of a higher demand for labour once a large number of foreign investors set up firms in the host countries. The decline in the unemployment rate and the increase in wage rate not only can reduce the poverty level but also increase the standard of living in the developing countries (Bjorvatn, Kind \& Nordas, 2001). A distinction has to be made between foreign direct investment (FDI) and foreign portfolio investment (FPI). Foreign direct investment occurs with direct investments in a foreign country. It includes ownership in fixed assets which can be difficult to divest in a short time. Unlike FDI, FPI is relatively more volatile. With a positive economic condition, FPI contributes huge funds that can 
contribute to a country's development. However, a drastic negative change in the economic conditions of a country can lead to huge a pull-out in portfolio investments from the country.

The expansion in FDI since then has substantially brought in large economic growth to ASEAN-5 which in turn increased the confidence of the foreign investors to make more physical investments in the region. According to the United Nations Conference on Trade and Development (UNCTAD), FDI inflow to ASEAN-5 increased from around an annual average US\$3 billion in 1983-1988 to US $\$ 14.1$ billion in 1989-1994. FDI inflows were still increasing at 5.8 per cent, from US\$25.2 billion in 1995 to US\$26.72 billion in 1996 . However, the total inflows of FDI dramatically dropped 33 per cent from US\$29.66 billion in 1997 to 19.7 billion in 1998. Even though there was some growth in total FDI inflow to ASEAN-5 in 1999 (at the level of US\$24.5 billion after the Asian financial crisis) the total ASEAN-5's FDI inflow had continually declined from 1999 until 2003 due to the economic recession in Japan, the US and Europe; the incident of September 11 in 2001, and the virus infection of Severe Acute Respiratory Syndrome (SARS). There was annual reduction in ASEAN-5's FDI inflows at an annual average decline rate of 14.3 per cent. Total global FDI inflows declined from US $\$ 134$ billion in 2000 to US $\$ 83$ billion in 2001, US\$72 billion in 2002 and US $\$ 63$ billion in 2003 before recovering marginally to US\$65 billion in 2004. FDI inflows to ASEAN-5 experienced a gradual expansion between the years 2003 and 2007; from US\$19.26 billion in 2003 to US\$61 billion in 2007. The ASEAN Economic Community (AEC) was introduced at the ninth ASEAN Summit in October 2003 with the objectives to improve ASEAN competitive power in attracting FDI and intra-ASEAN trade. Nevertheless, 2007 was a strong year for FDI inflow into ASEAN-5 countries as a whole. However, there was a small cutback in FDI in 2008 due to global financial crisis.

ASEAN-5 faces the challenge of China since it became a member of the World Trade Organization in December 2001. This led to China's improved investment environment with foreign investors. China became a major foreign direct investment destination as foreign investors perceived this country to have a huge market potential, with a population of 1.2 billion people. The question is does China have an effect on ASEAN-5's foreign direct investment? This study seeks the factors that contribute to FDI inflows to ASEAN-5 and also attempts to find whether the emergence of China has any impact on ASEAN-5 FDIs. 


\section{Literature Review}

Investors engage in FDI due to (a) net ownership possession advantages, (b) internalization activities advantages and (c) getting more benefits from the host country than the home country (Dunning, 1981; Cuyvers, Soeng, Plasmans \& Bulcke, 2011). The contribution of FDI towards economic growth is augmented by its positive interaction with human capital, macroeconomic policies and institutional stability (Yamin \& Sinkovics, 2008). Liu (2008) finds that the technological spill-over resulting from FDI produces a negative impact on productivity growth in the short term. However, there is a positive long-term growth rate in the productivity of local firms due to the time needed in investment expansion and the process of learning from the technological advantage of foreign investment.

Fan and Dickie (2000) argue that FDI inflows were used to stabilize ASEAN's economic development during the Asian financial crisis. The FDI is an extra source of capital inflow (other than saving and borrowing money from the international market which may induce certain risks in the event of a crisis). FDI provides financial risk diversification as there is risk-sharing between the foreign investor and the domestic firm which receives the foreign direct investment. Unlike portfolio investments and other types of access to foreign capital (which can bring serious problems to a country when there are reversal of capital inflows during financial crisis, i.e. capital flight), FDI is less volatile both during the good and bad times due to FDI's attributes. In other words, it would be easier to let go of the financial assets in a country but it would be a much difficult task to uproot an investment in real asset (via FDI) and look for another country to invest in. (Athukorala, 2003; Fan \& Dickie, 2000; Hill \& Jongwanich, 2009).

FDI is not only to be viewed as a source of capital, but also as an engine of technological development for the recipient countries via technology transfer. According to Sinani and Meyer (2004), technologies can be transferred through international trade by technologies embodied in new varieties of differentiated products/capital goods and equipment. Contractual agreements, such as licensing, may transfer technology by trade in intellectual property. There is also an indirect effect on technological progress and intensification of human skills in host countries resulting from FDI. Liu and Wang (2003) suggested that MNCs who invest in the host countries will bring advance technology which enables them to compete against local firms which are more familiar with local business practice, customer behaviour and market 
information. The elimination of the monopolistic power of the local firms after the entry of foreign firms will force local firms to adjust either by (a) using existing technology and resources more efficiently, (b) introducing new technologies or (c) imitating foreign technology in order to defend their market share.

FDI has an indirect effect on technological know-how spill-over. For example, saving in shipping cost and fulfilling the local customer preference, foreign firms in the host countries may choose to buy materials from the local suppliers. In order to control the quality of materials provided by the local suppliers in the host countries, MNCs will provide technical assistance and training as well as require suppliers to meet the standard of quality specified (Yudavae, Kozlov, Melentieva, \& Natalia, 2003). Normaz (2009) indicates that foreign firms which have taken over or undertaken joint venture with domestic firms might introduce well-organized management strategies. This enables local MNCs' employees to acquire new managerial skills.

A number of theories related to the factors affecting FDI have been developed and explained in conventional literature. For example, according to Helpman and Krugman (1985) and Krugman and Obstfeld (1994), the direction and the magnitude of capital flows are determined by different factors among countries. In particular, past studies cluster the key determinants of FDI into six groups (a) market size, (b) labour cost, (c) exchange rate, (d) interest rate, (e) the degree of openness and (f) corporate tax rate. Table 1 below summarizes the previous studies on these determinants.

\section{Table 1}

Summary of the Literature Review on the Factors Affecting FDI

\begin{tabular}{|c|c|}
\hline Factors & Findings \\
\hline \multirow[t]{3}{*}{ Market size } & $\begin{array}{l}\text { Host countries should possess a market size that is large enough to } \\
\text { meet the requirements of satisfactory domestic demand for products } \\
\text { to allow production to take place in the host country (Davidson, 1980; } \\
\text { Colongeli, 2010; \& Cuyvers, 2011). }\end{array}$ \\
\hline & $\begin{array}{l}\text { Reduction in the cost of entry through the economy's scale can be } \\
\text { exploited in larger markets (Ramasamy \& Yeung, 2010). }\end{array}$ \\
\hline & $\begin{array}{l}\text { A host country, with favourable market opportunities, allows MNCs to } \\
\text { exploit their ownership advantage and also to gain in the economy's of } \\
\text { scale (Cuyvers et al., 2011). }\end{array}$ \\
\hline
\end{tabular}

(continued) 
IJMS 20 (1), 77-108 (2013)

\begin{tabular}{ll}
\hline Factors & Findings \\
\hline Market factor is mainly used as a determinant of FDI flow to the \\
manufacturing sector. However, the size of the market might be less \\
prominent and insignificant as the determinant of FDI when MNCs use \\
hostcountriesasproductionbasestomakegreaterprofitsbyexploiting the \\
cost advantage of production in the host countries (Chakrabarti, 2001).
\end{tabular}

Market size is a significant determinant of the direction of Japanese FDI inflow for developed countries particularly large firms (Urata \& Kawai, 2000).

The coefficient of correlation between market size and the level of FDI inflows to Mauritius is small due to the small economy in Mauritius with limited domestic market potential (Seetanah \& Rojid, 2011).

Labour cost MNCs engaged in producing labour-intensive products would focus on looking for host countries that have lower labour costs in order to get greater cost-effective production (Ramasamy \& Yeung, 2010; and Daly \& Tosompark, 2011).

The impact of labour cost on FDI into the host country is negative when there is efficiency-seeking FDI (Thomas \& Grosse, 2001).

Cheaper cost of labour attracts more foreign investments. This is supported by the dependency hypothesis and the modernization hypothesis. In the dependency theory, MNCs manage high-paying white collar jobs located in the home country, while seeking cheap blue collar jobs from the host country. Modernization theorists argue that the international division of labour resulting from specialization can bring in mutual gain from trade (Chakrabarti, 2001).

Cheap labour encourages inbound FDI over the period 1983-1986 but finds weak association for the period from 1975-1978 (Tsai, 1994).

There is a positive link between labour cost and FDI in the electronic industry (Wheeler \& Mody, 1992).

There is a negative association between labour cost and inbound of FDI in European countries (Bevan \& Estrin, 2004).

Labour cost in the host country has a negative impact on the Japanese FDI inflow to the host country. Japanese firms look for locations with lower wage rates as their FDI destination (Urata \& Kawai, 2000).

Increasing wage is associated with increasing in FDI inflows (Lucas, 1993; and Yang et al., 2000).

A positive link between wage and FDI inflows implies that higher paying labour means better labour quality that foreign investors are looking for (Daly \& Tosompark, 2011). 


\begin{tabular}{|c|c|}
\hline Factors & Findings \\
\hline \multirow[t]{3}{*}{$\begin{array}{l}\text { Cost of } \\
\text { borrowing }\end{array}$} & $\begin{array}{l}\text { The higher the interest rates in the host country, the greater the } \\
\text { attractiveness of the country as host to FDI (Daly \& Tosompark, 2011). }\end{array}$ \\
\hline & Interest rate is positively related to FDI inflow (Yang et al., 2000). \\
\hline & $\begin{array}{l}\text { Large amounts of fund can be raised from the financial system in the } \\
\text { host country, so that the higher cost of capitals of host the country } \\
\text { can negatively affect the amount of FDI flow into the host country } \\
\text { (Ramasamy \& Yeung, 2010). }\end{array}$ \\
\hline
\end{tabular}

Discount rate is negatively related to FDI inflows (Petrochilas, 1989; and Zhao, 2003).

There is a negative relationship between interest rate and FDI inflow in long-run horizons (Moshirian, 1997).

Exchange There are two reasons why the level of the exchange rate in the host rate country can affect the flow of FDI from foreign investors into the country. First, devaluation in the currency of the host country leads to the reduction in the production cost of the foreign investor in terms of the home country's currency, therefore, MNCs who are export-oriented can reap a large profits from it. Second, the exchange rate can influence the purchasing power of MNCs in acquiring domestic assets expressed in local currency (Lee \& Min, 2011).

Wealth effect - The depreciated local currency makes the price of input such as labour, land, equipment, machines and other assets cheaper for MNCswhosecapitalisinforeigncurrency, promotes them toacquiremore domestic assets in comparison with local players (Wan \& Xing, 2006).

Capital market friction - Foreign investors finance their bid for foreign investment projects abroad through bank loans, but the amount of bank loan depends on the net worth of the firm in terms of foreign currency which, in turn, relies on the exchange rate. Therefore, an appreciation of foreign currency increases the wealth of the foreign firms and enables them to invest with low-cost fund relative to local competitors (Froot \& Stein, 1991).

If the motive behind FDI is to acquire moveable assets (firm specific assets, managerial skills, and technological know - how and etc.) which can be transferred across many markets without currency transactions, then, FDI increases with devaluation in the currency of the host country (Blonigen, 1997; and Buch \& Kleinert, 2008).

There is a positive relationship between depreciation in the local currency and the FDI inflow to China (Liu et al., 1997; and Wei \& Liu, 2001).

If FDI is invested in the host country for the intention of serving the local market, then an appreciation in the currency of the host country is favourable. It is because the higher value of the country currency can increase the purchasing power of the local consumers (Daly \& Tosompark, 2011). 
IJMS 20 (1), 77-108 (2013)

\begin{tabular}{ll}
\hline Factors & Findings \\
\hline In the long run, there is a negative impact from the devaluation in the \\
local currency on the amount of earnings that can be remitted to the \\
home country. The stream of return on investments might fall in terms \\
of the currency of the country of origin as a result of devaluation in the \\
host country's currency (Razafimahefa \& Hamori, 2007; and Wijeweera \\
\& Mounter, 2008).
\end{tabular}

The instability of the exchange rate can increase the uncertainty of the return of the investments from MNCs, which delay MNCs' FDI. On the other hand, there is a positive relationship between the volatility of the exchange rate and FDI inflow to the host country when the domestic market is a substitute to exporting (Lee \& Min, 2011).

Corporate A higher tax rate in the host country will make the location for FDI tax rate become less attractive taking into account the net profit after tax (Wijeweera et al., 2007).

Corporate tax rate is an important factor that points to the attractiveness of the host country in attracting foreign direct investors. A decrease in the tax level in the host country is a valuable incentive for FDI in the country (Seetanah \& Rojid, 2011).

Reducing the corporate tax rate would positively affect the growth of FDI. Tax rate is statistically significant in explaining the FDI in Pakistan and determining the growth of FDI in long run or short run (Aqeel \& Nishat, 2004).

Negative relationship between tax and FDI. A study indicates that tax has a positive effect on inward FDI (Swensen, 1994).

Foreign investors increase investment in response to the higher corporate tax rate in the US (Scholes \& Wolfson, 1990).

Studies find no support on the impact of taxes on FDI (Hines \& Rice, 1994) and Hines, 1996).

Degree of "Tariff Hoping" hypothesis states that high trade barriers do not favour openness MNCs who export goods to the host country. This hypothesis posits that the relationship between openness and FDI is negative (Krugel, 2005).

In order to stay away from high trade cost, MNCs would choose to enter the market through FDI and serve their consumers with local facilities instead of exporting (Wang \& Swain, 1997).

Trade and FDI are substitutes for each other. FDI inflows to the host countries will probably decrease with the increase in the level of trade openness in the host countries as FDI can be substituted by trade (Markusen, 2002). 
IJMS 20 (1), 77-108 (2013)

\begin{tabular}{|c|c|}
\hline Factors & Findings \\
\hline & $\begin{array}{l}\text { A high degree of openness discourages market-oriented FDI because } \\
\text { the market might then be served through export. If restrictions on trade } \\
\text { are rigorous, the favoured solution would be making direct investments } \\
\text { in the target country in order to serve the market locally (Seim, 2009). }\end{array}$ \\
\hline & $\begin{array}{l}\text { The openness of a country causes adverse impact on the FDI inflows. } \\
\text { FDI inflows are substitute for trade (Yang et al., 2000). }\end{array}$ \\
\hline & $\begin{array}{l}\text { There is a high degree of openness as a result of low trade barriers } \\
\text { encouraging FDI inflows to the ASEAN region (Normaz, 2009). }\end{array}$ \\
\hline & $\begin{array}{l}\text { Southeast Asian countries' FDIs are more elastic with respect to the } \\
\text { demand for exports, than with respect to the aggregate domestic } \\
\text { demand (Lucas, 1993). }\end{array}$ \\
\hline & $\begin{array}{l}\text { FDI's are more attracted to the country where the economy is export- } \\
\text { oriented (Jun \& Singh, 1997). }\end{array}$ \\
\hline & $\begin{array}{l}\text { There is short-run positive effect on the FDI inflows. Foreign investors } \\
\text { are more concerned with the openness of the economy's trade policy in } \\
\text { recent periods rather than the historical policy (Wijeweera \& Mounter, } \\
2008 \text { ). }\end{array}$ \\
\hline
\end{tabular}

\section{The Influence of China}

According to Puah et al. (2007), the entry of China into WTO transformed China into the hub for FDI flow into the Asian region which in turn further increased its GDP growth rate over 9 per cent in 2003 and in 2004. Foreign investors are now provided with new investment opportunities to invest in China in sectors that were previously closed or highly restricted to foreign firms such as telecommunication services, wholesaling and retailing, logistics, financial services, travel and tourism, and audio visual-related activities. Politicians and academicians in the ASEAN countries fear that the rising Chinese economy will hurt ASEAN member economies (Ravenhill, 2006) as China could suck all the FDIs away from the ASEAN region. There are different points of view among economists on the impact of China's WTO accession on the inward FDI in ASEAN-5 or ASEAN as a whole.

According to Freeman and Bartels (2004), there are three possible outcomes as the consequence of ASEAN countries being affected as host's for FDI by China opening up its international market. They are; (a) magnetic effect, (b) neutral effect, and (c) benign effect outcomes. The first outcome is a zero-sum game. China's locational advantages for FDI are stronger compare to the Southeast Asian countries, creating 
the tendency for foreign-owned operations in the region to shift to China. This is the so-called magnetic effect argument. The second possible outcome is that, once the initial euphoria of China's entry has waned, regional investment flows will readjust to bring about a more equitable distribution of FDI across East and Southeast Asia. This is the neutral effect argument. Next, the third possible scenario is that as China attracts greater shares of global and regional FDI flows, the Southeast Asian Countries could somehow piggyback on China, and negate any detrimental effects to their own economic development that might otherwise occur. This is the benign effect argument.

Some past studies assert that China will be a threat to ASEAN-5 in areas which require labour-intensive production, as low labour cost is one of China's comparative advantages (Lall, 2003). China is an attractive location for FDI as there is lower labour cost and a larger market size relative to the ASEAN-5 countries. Labour cost occupies a larger percentage of the total production cost. A lower labour cost in China helps MNCs to gain competitive advantage. There is a perception of extensive FDI diversion to China from developing countries to take advantage of the large domestic market and to seek for more efficient production locations (Rajan, 2003a and b). China absorbs a large share of FDI flows into developing countries from the MNCs of Japan, the US, and the EU. In the past, the Japanese dominated the FDI in ASEAN countries, but it was surpassed by the EU and the US between 1995 and 2008. According to the JOI Bulletin (2011), this may be due to Japan shifting its investment to other countries such as, China and India.

However, several econometric studies have suggested that FDI inflow into China in fact, has a positive effect on the inward FDI in ASEAN. Chantasasawat et al. (2004) conducted an econometric analysis using the panel data regression method to analyse on the effect of China's inflow of FDI in the East and Southeast Asian countries. The researchers estimated that an increase in the level of FDI inflow into China by 10 per cent will contribute to approximately 5 per cent to 6 per cent increase in FDI inflow to the East and Southeast Asian countries. Zhou and Lall (2005) used the same approach and obtained the same result to support that the level of FDI flow into China has a positive effect on investment flows into Southeast Asia. Ravenhill (2006) suggests several reasons for this positive effect. One of them is that sharp expansion of industrialization in China helped develop 
a huge appetite for minerals and raw materials. This resulted in an upsurge of FDI flow into ASEAN countries which have the resources or raw material that can feed China's appetite. According to Puah et al. (2007), the rise of China cannot be regarded as a zero-sum game from the standpoint of FDI where a larger stream of FDI into China is at the expense of FDI inflow to ASEAN countries. They perceived that the rise of China might leave an adverse effect on ASEAN-5 in the short run, but the potential economic profit to ASEAN-5 far outweighs the cost. According to them, this is because China's economy is gradually and subsequentially shifting from being exported-oriented to a more domestic demand driven economy. This provides more opportunities for the ASEAN-5 countries (Zhang \& Ow, 1996; Srivastava \& Rajan, 2003). As a member of WTO, China is opening up its massive market for imports and thus offering huge opportunities to neighbouring countries (Abeysinghe \& Lu, 2003).

\section{Methodology}

The vector autoregressive (VAR) method was used to examine how FDI inflow responds to the changes in the explanatory variables chosen for this study (i.e. market size, labour cost, interest rates, exchanges rates, corporate tax rates, degree of openness, and China's entry into WTO). The VAR model has certain advantages in that in a VAR model, dependent variables are expressed as functions of their own and each other's lagged values and all the variables are allowed to affect each other (Enders, 1995). The general form of the VAR can be written as:

$$
\Delta y_{t}=a_{0}+a_{2} t+\gamma y_{t-1}+\sum_{i=2}^{p} \beta_{i} \Delta y_{t-i-1}+\varepsilon_{t}
$$

Where $y_{t}$ denotes the $t_{\text {th }}$ observations for $n$ stationary variables; $p$ denotes the number of autoregressive lags; $\beta_{j}(j=1, \ldots, p)$ denotes an $n \times n$ matrix of autoregressive coefficients, and $\varepsilon$ denotes the error term.

The first step of the analysis is to test for the presence of unit roots in the variables in the system using the Augmented Dicky-Fuller (ADF) test in order to ensure that they enter the model at the stationary level. Dickey-Fuller (1979) suggested a statistical procedure for testing the null hypothesis of non-stationarity. It is important to note that if 
the unit root test result shows that all the variables are integrated in the same order, then a Vector Error Correction Model (VECM) can be constructed. However, if not all the variables are integrated of the same order the unrestricted VAR model will be estimated. The unrestricted VAR model consists of variance decomposition (VDC) and impulse response function (IRF). Variance decomposition permits inference to be drawn regarding the proportion of the movement in a particular time series which are attributable to the shocks to each variable in the model. Impulse response functions trace the time path of the effects of the shocks of the other variables contained in the VAR on a particular variable.

The objectives of this study are to: (a) identify the factors affecting FDI in countries in the Association of Southeast Asian Nations (ASEAN) region and (b) examine the effect of China's entry into the WTO on the FDI in the ASEAN countries. The dependent variable for this study is inward foreign direct investment and the independent variables are market size, labour cost, exchange rate, interest rate, the degree of openness and the corporate tax rate. In addition, to study the effect of China's entry into the WTO on FDI, a dummy variable is used. The effect of China is represented by a dummy variable, with a value of ' 0 ' representing the period prior to China's entry into the WTO and ' 1 ' representing the period after China's entry into the WTO. The data are retrieved from Thomson DataStream, IMF and the World Bank.

The log transformation is applied to ensure linearity in both parameters and variables. The model that is used in this study is expressed as follows:

LFDI $=f$ (LPCRGDP, LLABOR, LRINT, LREXC, LTAX, LOPENESS, CHINA)

Where:

LFDI $\quad=$ Log of annual inflows of FDI in each country in ASEAN-5

LPCRGDP $\quad=$ Log of GDP Per Capita (in US Dollar \$)

LLABOR $\quad=$ Log of Real GDP divided by Labour Force (in US Dollar \$)

LRINT = Log of Real interest rate (per cent)

LREXC = Log of Real exchange rate (per cent) 


\section{LOPENESS}

LTAX

CHINA (DUM)
$=$ Log of Sum of imports and exports as percentage of GDP

$=$ Log of Corporate tax rate (per cent)

$=1$ for the period 2001 to 2010, 0 otherwise.

Market size has been considered as one of the most important factors affecting FDI. Some empirical studies have used absolute GDP as the proxy for market size. However, it has been pointed out that absolute GDP is not suitable to be the proxy for market size because absolute GDP is a poor indicator of market potential in developing countries as it tends to reflect the size of the population rather than the income level of the country. Since, our sample of the study is in the category of developing countries, the GDP per capital is chosen as proxy for market size. According to Azemar and Desborder (2010), low labour cost is an attractive element that can absorb a large share of FDI inflow to host countries as long as low labour cost is in line with low productivity. Due to insufficient data on labour costs in ASEAN-5, labour cost is measured by real GDP divided by labour force, and will be used as a proxy variable for the real wage rate. Some authors have used this as a proxy for the real wage rate (e.g. Ioannatos, 2001).

Real interest rate is a nominal interest rate that has been adjusted for inflation. According to Singhania and Gupta (2011), the reason for this is that an investor will look for cheaper funding options as well as higher returns on the money invested in other countries. A country with a relatively higher rate of interest and lower borrowing cost would have a greater prospect of FDI inflow to the host countries. The weaker the currency of a country the less likely it is that foreign firms will invest in that location (Chakrabarti, 2001).This study uses the corporate tax rate as one of the independent variables in line with Bartik (1985). Similar to the study by Singhania and Gupta (2011), the degree of openness is defined by the total sum of exports and imports divided by GDP. According to Chakrabati (2001), given that most investment projects are directed towards the tradable sector, a country's degree of openness to international trade should be a relevant factor in the decision. Finally, in order to find the effect of China on the FDIs in ASEAN-5, a dummy variable is used. CHINA is the dummy variable, defined as being equal to 1 for the years China became a member of the WTO (2001-2010) and zero otherwise. VAR analysis is employed to test the impact of the variables for this study on the annual of inflow FDI for each member of ASEAN-5. 


\section{Findings}

Tables 1 to 5 in Appendix 1 present the results of the unit root test for each variable of each country. Based on the tables, the ADF test reports that most of the variables for the five countries are nonstationary. The non-stationary series become stationary after taking their first difference. According to Zivengwa et al. (2011), if the v0, if the variables are integrated of different order, the unrestricted VAR model should be used instead of the vector error correction model (VECM).

The vector autoregressive method (VAR) is applied to examine the impact of each variable for this study on FDI inflow in ASEAN-5. Table 6 shows the variance decomposition of FDI (LFDI) for Indonesia. The LFDI for Indonesia is not purely exogenous as only about 31.67 per cent of the variance in the FDI for Indonesia is due to its own shocks in the first period. Much of the innovation in FDI for Indonesia is explained by the China effect which contributes a maximum of 50.50 per cent in the second period but its impact declines over time. The deviation of FDI for Indonesia is attributable to the China effect with a percentage of about 16.21 per cent at the end of a 10-year period. However the China effect can still be considered as the most important variable that explains the innovation in FDI for Indonesia. The contribution of the interest rate to explain innovation in FDI is large. The interest rate contributes a maximum of 31.42 per cent and then remains above 20 per cent over the period. Furthermore, the contribution of labour costs increases over time and contributes a maximum of 17.72 per cent in the ninth period. This indicates that labour cost is still considered as an important determinant of FDI for Indonesia. The corporate tax rate contributes a maximum of 22.48 per cent in the second period and its impact goes down over time after the period. The contribution of the corporate tax rate to the deviation in FDI for Indonesia is 12.87 per cent in the $10^{\text {th }}$ period. Despite that, the corporate tax rate is another major variable to explain FDI inflow to Indonesia. On the other hand, the degree of openness on trade, market size and real exchange rate is highly insignificant to explain variance in FDI for Indonesia, as they contribute a maximum of 3.59 per cent in the sixth period, 3.18 per cent in the tenth period and 0.18 per cent in the ninth period, indicating the relationship is weak. 
IJMS 20 (1), 77-108 (2013)

Table 6

Variance Decomposition LFDI for Indonesia

\begin{tabular}{cllllllll}
\hline Period & CHINA & LFDI & LRINT & LLABOR & LPCRGDP & LOPENNESS & LREXC & LTAX \\
\hline 1 & 51.5222 & 31.668 & 16.8098 & 0 & 0 & 0 & 0 & 0 \\
2 & 54.504 & 19.4177 & 12.3123 & 4.44019 & 0.295594 & 3.531874 & $2.18 \mathrm{E}-05$ & 5.49836 \\
3 & 38.8599 & 10.0632 & 31.4162 & 1.836283 & 0.133209 & 2.910808 & 0.22036 & 14.5601 \\
4 & 34.2701 & 12.8071 & 30.3395 & 2.069475 & 0.373922 & 2.094953 & 0.85835 & 17.1866 \\
5 & 27.2528 & 12.7344 & 27.1396 & 5.939555 & 0.912915 & 3.146992 & 0.68471 & 22.189 \\
6 & 25.3204 & 13.474 & 24.3376 & 8.784614 & 1.334517 & 3.590739 & 0.67846 & 22.4797 \\
7 & 19.1695 & 18.8421 & 23.1219 & 16.83851 & 1.524496 & 2.711617 & 0.7648 & 17.0271 \\
8 & 19.3594 & 18.9296 & 22.2848 & 16.60294 & 2.843126 & 2.687386 & 0.74279 & 16.55 \\
9 & 16.5185 & 19.9245 & 26.4319 & 17.71878 & 2.563402 & 2.531684 & 0.87909 & 13.4322 \\
10 & 16.2194 & 20.405 & 26.8886 & 16.93647 & 3.182062 & 2.639358 & 0.85751 & 12.8716 \\
\hline
\end{tabular}

Table 7 shows the variance decomposition of LFDI for Singapore. Most of the innovation in the FDI for Singapore is attributable to its own shock especially in the first period with a percentage of 96.35 per cent. In the second period, the 57.08 per cent of deviation in FDI for Singapore is attributable to itself. The effect of China contributes to the deviation in FDI for Singapore with a percentage of 29.75 per cent in the second period and a maximum of 33.64 per cent in the fourth period and then remains around 32 per cent to 31 per cent after the fourth period. This is an important variable that explains the FDI for Singapore. Next it is followed by the degree of openness which contributes a maximum of 13.37 per cent to the deviation in the FDI for Singapore in the third period, but the impact of the degree of openness declines after the third period and contributes to the deviation in FDI for Singapore with a percentage of 10.88 per cent in the tenth period, indicating that the degree of openness is still an important cause of FDI in Singapore as compared to the effect of other variable shocks on FDI for Singapore. The deviation in FDI for Singapore cannot be mainly explained by real interest rate, market size, labour cost and real exchange rate and corporate tax rate because the contribution of these variables is highly insignificant contributing a maximum of 3.35 per cent in the $10^{\text {th }}$ period, 3.45 per cent in the $10^{\text {th }}$ period, 2.53 per cent in the $9^{\text {th }}$ period, 4.52 per cent in the $3^{\text {rd }}$ period and 1.28 per cent in the $10^{\text {th }}$ period. This shows that these five variables have small effect on variance in FDI for Singapore. 
IJMS 20 (1), 77-108 (2013)

Table 7

Variance Decomposition LFDI for Singapore

\begin{tabular}{cllllllll}
\hline Period & CHINA & LFDI & LRINT & LLABORE & LPCRGDP & LOPENNESS & LREXC & LTAX \\
\hline 1 & 3.65175 & 96.3483 & 0 & 0 & 0 & 0 & 0 & 0 \\
2 & 29.7455 & 57.0839 & 0.00047 & 0.387427 & 0.111737 & 11.66402 & 0.90212 & 0.10487 \\
3 & 25.501 & 51.2773 & 2.92978 & 0.921045 & 2.913348 & 11.97404 & 3.40624 & 1.07727 \\
4 & 33.6426 & 40.9387 & 2.14818 & 2.314486 & 2.20557 & 13.36751 & 4.51803 & 0.86489 \\
5 & 32.7978 & 40.8803 & 3.20888 & 2.267777 & 2.545718 & 13.00553 & 4.41745 & 0.8765 \\
6 & 32.4405 & 42.8019 & 3.04704 & 3.061016 & 2.568001 & 11.37861 & 3.86262 & 0.84033 \\
7 & 32.2012 & 42.6878 & 3.02313 & 3.180874 & 2.527293 & 11.23553 & 3.91595 & 1.22825 \\
8 & 31.9722 & 42.8326 & 3.00006 & 3.351649 & 2.528515 & 11.04347 & 4.00758 & 1.26391 \\
9 & 31.9225 & 42.7591 & 3.14212 & 3.350547 & 2.531855 & 10.99712 & 4.01132 & 1.28545 \\
10 & 31.8693 & 42.6869 & 3.34837 & 3.447297 & 2.497344 & 10.88668 & 3.97652 & 1.28764 \\
\hline
\end{tabular}

Table 8 shows the variance decomposition of LFDI for Malaysia. From the table, it can be seen that all the shocks are not attributable to its own shock for any given period. The LFDI for Malaysia is not purely exogenous. In the first period, about 40.15 per cent of deviation in FDI for Malaysia is explained by its own shock. Much of the variance in FDI for Malaysia is attributable to the China effect (CHINA), which contributes much to the deviation in FDI for Malaysia with a percentage of 59.85 per cent in the first period. However, the impact of the China effect shock declines over time, implying that the deviation in FDI for Malaysia is explained by other variables. For Malaysia, the market size (LPCRGDP) variable impact on LFDI increases over time. The market size contributes a maximum of 26.65 per cent in the ninth period; implying that market size is the major determinant of FDI for Malaysia over the period. Labour cost (LLABOR) contributed over 14 per cent to variance in FDI for Malaysia with labour cost contributing a maximum of 17.52 per cent in the eighth period, indicating this is an important variable that explains FDI for Malaysia. Real exchange rate (LREXC) is also another variable and its impact on FDI in Malaysia increases over time. The deviation in FDI for Malaysia is attributable to real exchange rate with a maximum of 13.45 per cent in the seventh period. The degree of openness (LOPENESS)'s has a low effect on FDI for Malaysia over time. It contributes a maximum of 11.41 per cent of deviation in FDI for Malaysia in the second period but decreases over time contributing only 5.27 per cent at the end of the 10-year period, which indicates that there is a weak relationship between 
the degree of openness and FDI in Malaysia. The contribution of the corporate tax rate (LTAX) and the real interest rate (LRINT) is highly insignificant contributing a maximum of 9.15 per cent in the second period and of 3.95 per cent in the $3^{\text {rd }}$ period.

Table 8

Variance Decomposition LFDI for Malaysia

\begin{tabular}{cllllllll}
\hline Period & CHINA & LFDI & LRINT & LLABOR & LPCRGDP & LOPENNESS & LREXC & LTAX \\
\hline 1 & 59.8451 & 40.1549 & 0 & 0 & 0 & 0 & 0 & 0 \\
2 & 41.5882 & 16.2847 & 0.00777 & 8.516608 & 9.574916 & 11.4146 & 7.19034 & 5.4229 \\
3 & 28.8391 & 11.45 & 3.95177 & 14.74684 & 16.18165 & 8.08018 & 7.60067 & 9.14975 \\
4 & 21.3868 & 12.8115 & 3.21854 & 15.8397 & 22.09998 & 6.793219 & 10.8333 & 7.01698 \\
5 & 19.1745 & 20.0668 & 3.00037 & 14.37415 & 20.81495 & 6.136865 & 9.7017 & 6.73074 \\
6 & 19.2538 & 18.7912 & 3.75659 & 16.61222 & 19.83013 & 5.741994 & 9.87597 & 6.13806 \\
7 & 16.3776 & 16.737 & 3.61567 & 16.74007 & 21.65769 & 5.755991 & 13.4521 & 5.66396 \\
8 & 15.2074 & 15.6099 & 3.67484 & 17.52298 & 24.05115 & 5.533544 & 13.2534 & 5.1468 \\
9 & 14.1703 & 14.8718 & 3.41599 & 17.35334 & 26.65728 & 5.398857 & 12.9949 & 5.13751 \\
10 & 13.8806 & 16.269 & 3.30208 & 17.1238 & 26.47542 & 5.270093 & 12.5652 & 5.11382 \\
\hline
\end{tabular}

Table 9 shows the variance of decomposition of LFDI for Thailand. In the first period, LFDI for Thailand can be said to be purely exogenous as almost about 99.89 per cent deviation in the variable is explained by its own shocks. Over time, the other variables began to explain the shocks in this variable as shown by dropping from 99.89 per cent in the first period to 65.61 per cent in the tenth period. However, all the other variables are still highly insignificant in explaining the shocks of FDI for Thailand over time. The labour cost is the only variable which has contributed almost a maximum of 10 per cent to the deviation in FDI for Thailand in the fourth period and for the remaining period the deviation is over 9 per cent. Real interest rate contributes a maximum of 9.15 per cent to the shocks in FDI for Thailand and over 8 per cent for the remaining period. Even though, the effect of the real exchange rate increases over time it only contributes a maximum of 6.83 per cent in the ninth period. The effect of China contributes a maximum of 5.70 per cent and this occurs in the sixth period. Market size contributes a maximum of only 2.14 per cent of innovation in FDI for Thailand and this happens in the third period. While the degree of openness and corporate tax rate only contribute a maximum of 1.07 per cent in the seventh period and 0.96 per cent in the fifth period. Thus, it indicates that the relationship between these 7 variables and FDI for Thailand is weak. 
IJMS 20 (1), 77-108 (2013)

Table 9

Variance Decomposition LFDI for Thailand

\begin{tabular}{cllllllll}
\hline Period & CHINA & LFDI & LRINT & LLABOR & LPRCRGDP & LOPENNESS & LREXC & LTAX \\
\hline 1 & 0.13246 & 99.8675 & 0 & 0 & 0 & 0 & 0 & 0 \\
2 & 2.22166 & 89.1032 & 4.89006 & 0.08529 & 0.328376 & 0.232268 & 2.3989 & 0.74029 \\
3 & 4.41533 & 83.9526 & 4.92068 & 0.646235 & 2.125027 & 0.937115 & 2.23931 & 0.76376 \\
4 & 4.18553 & 75.4246 & 6.55701 & 7.26828 & 2.141213 & 0.834452 & 2.87366 & 0.71531 \\
5 & 4.18202 & 72.332 & 7.58062 & 9.898972 & 1.901864 & 0.795439 & 2.55368 & 0.75546 \\
6 & 5.69689 & 69.4866 & 9.15304 & 9.465814 & 1.736627 & 0.981681 & 2.51572 & 0.9636 \\
7 & 5.50517 & 66.9899 & 8.99688 & 9.187285 & 1.938339 & 0.979413 & 5.4738 & 0.92923 \\
8 & 5.43203 & 65.9486 & 8.91114 & 9.086036 & 1.93326 & 1.067405 & 6.68462 & 0.93695 \\
9 & 5.41147 & 65.7334 & 8.8395 & 9.247463 & 1.953665 & 1.057305 & 6.82654 & 0.93064 \\
10 & 5.52553 & 65.6152 & 8.84482 & 9.227511 & 1.965757 & 1.064234 & 6.82117 & 0.93578 \\
\hline
\end{tabular}

Table 10 shows the decomposition of LFDI for the Philippines. In the first period, FDI for the Philippines is not purely exogenous because all the deviations in FDI for the Philippines are not attributable to its own shocks for any given period. In the early years, much of the deviation in the FDI for the Philippines is attributable to itself especially in the first period with a percentage of about 58.63 per cent but it then declines over time, indicating the importance of other variables in explaining the variance in FDI for the Philippines. The China effect contributes a maximum of 41.36 per cent of the deviation of FDI for the Philippines and this occurs in the first period. The contribution of the effect of China declines gradually over time and its contribution is 25.2 per cent in the tenth period, indicating the effect of China is still a major determinant of FDI for the Philippines. The effect of the real exchange rate increases over time and contributes a maximum of 13.79 per cent in the tenth period. The labour cost is also an important variable in explaining the deviation of FDI for the Philippines. The impact of labour cost shocks contributes a maximum of 11.18 per cent in the tenth period. The deviation in FDI for the Philippines is attributable to real interest rate increase steadily over time and contributes a maximum of 8.77 per cent in the ninth period. This shows that real interest rate is an important determinant of FDI inflows in the Philippines. Market size, corporate tax rate and the degree of openness contribute a maximum of 3.43 in the sixth period, 4.78 per cent in the tenth period and 0.58 per cent in the fifth period. 
Table 10

Variance Decomposition LFDI for Philippines

\begin{tabular}{cllllllll}
\hline Period & CHINA & LFDI & LRINT & LLABOR & LPCRGDP & LOPENNESS & LTAX & LREXC \\
\hline 1 & 41.3604 & 58.6397 & 0 & 0 & 0 & 0 & 0 & 0 \\
2 & 32.8171 & 52.0167 & 4.02055 & 8.464875 & 1.830398 & 0.333439 & 0.51529 & 0.00172 \\
3 & 32.4042 & 41.6837 & 3.63728 & 11.085878 & 3.016229 & 0.287851 & 0.52273 & 2.87019 \\
4 & 29.7412 & 39.6816 & 4.34917 & 10.649004 & 3.263243 & 0.569201 & 0.87645 & 4.73366 \\
5 & 30.6064 & 37.9526 & 4.1669 & 10.540639 & 3.119488 & 0.58504 & 0.93402 & 9.93262 \\
6 & 29.3512 & 36.4162 & 3.99826 & 11.159818 & 3.439661 & 0.525304 & 1.75088 & 11.1476 \\
7 & 28.3888 & 35.1859 & 6.13862 & 10.947498 & 3.390321 & 0.573166 & 2.29489 & 13.1336 \\
8 & 28.0811 & 34.94 & 6.81074 & 10.840546 & 3.347382 & 0.573429 & 2.49732 & 12.6536 \\
9 & 25.8928 & 32.1935 & 8.76922 & 10.948088 & 3.265392 & 0.575927 & 4.45987 & 12.273 \\
10 & 25.2085 & 31.8953 & 8.50656 & 11.183053 & 3.292396 & 0.560113 & 4.78515 & 13.7893 \\
\hline
\end{tabular}

In conclusion, labour cost has an impact on FDI for Indonesia, Malaysia, Thailand, and the Philippines. This is in line with the studies by Daly and Tosompark (2011) and Ramasamy and Yeung (2010). Similar to Zhao (2003), the cost of borrowings (interest rates) contributes to the FDI flows into Indonesia, Thailand, and the Philippines. In accordance with Lee and Min (2011), the movements of exchange rates impact FDI into Malaysia and the Philippines. Corporate tax rates affect the movement of FDI in Indonesia. This is in line with Wijeweera et al. (2007) and Seetanah and Rojid (2011). In agreement with Normaz (2009), the degree of openness provides an impact on FDI into Singapore. However, market size does not have a significant role in the movement of FDI into all the ASEAN-5 countries being studied. This is in line with Chakrabarti (2001). In terms of the entry of China into the WTO, similar to Lall (2003), all the ASEAN-5 countries are affected by it except Thailand. Nonetheless, the impulse response functions show that all the variables are meanreverting (see Appendix 2).

\section{Conclusion}

This paper examines the factors that might affect the level of inward FDI in ASEAN-5 member countries (Indonesia, Malaysia, Singapore, Thailand and the Philippines) from 1980 to 2010. The VAR analysis is used to identify the dynamic relations of FDI inflow into ASEAN-5 as a result of changes in the explanatory variable chosen. The finding from this study provides a clearer picture regarding the factors 
affecting the level of inward FDI to ASEAN- 5 and can be utilized by policy makers to focus on the relevant factors that exert significant influence on FDI in ASEAN-5 and draw up a well-defined strategy for FDI.

With respect to policy implication for member countries of ASEAN-5, it is important to highlight that China's rising economy does influence the pattern of FDI inflows to ASEAN-5. Therefore, it is suggested that ASEAN policymakers should exercise close diplomatic practices in order to have a healthy bilateral relationship between ASEAN-5 and China. In addition, the manner in which interest rate policies are adopted by the Indonesian, Thai, and the Philippines governments will have significant impacts on the level of inward FDI in the three countries. For Malaysia, Indonesia, Thailand, and the Philippines, there is a relationship between labour cost and inbound FDI. These governments should increase the quality of their labour force in order to enhance the quality of human capitals which are highly demanded by MNCs. This, in turn, increases their competitiveness to attract more FDI inflows to the country. The level of exchange rate affects FDI in Malaysia and the Philippines. Malaysia and the Philippines should ensure that their exchange rate policies remain attractive in favour of attracting FDIs. Indonesia should pay more attention on its corporate tax rate as it affects the in-flow of FDI into Indonesia. The degree of openness is a key determinant of FDI inflows to Singapore but its impact of openness declines with time. Thus, the Singaporean policymakers should not, for example, be over dependent on reducing tariff and lessening restrictions to attract FDI.

\section{References}

Abeysinghe, T., \& Lu, D. (2003). China as an economic powerhouse: Implications on its neighbors. China Economic Review, 14, 164-185.

Athukorala, P. C. (2003). Foreign direct investment in crisis and recovery: Lessons from the 1997-1998 Asian crisis. Australian Economic History Review, 43(2), 197-213.

Aqeel, A., \& Nishat, M. (2004). The determinants of foreign direct investment in Pakistan. The Pakistan Development Review, 43(4), 651-664.

Bartik, T. J. (1985). Business location decisions in the United States: Estimates of the effects of unionization, taxes, and other characteristics of states. Journal of Business $\mathcal{E}$ Economic Statistics, American Statistical Association, 3(1), 14-22. 
Bevan, A. A., \& Estrin, S. (2004). The determinants of foreign direct investment into European Transition Economies. Journal of Comparative Economics, 32, 775-787.

Bjorvatn, K., Kind, H. J., \& Nordas, H. K. (2001). The role of FDI in economic development. Published Working Paper. The Research Council of Norway.

Blonigen, B. A. (1997). Firm-specific assets and the link between exchange rates and foreign direct investment. American Economic Review, 87(3), 447-465.

Buch, C. M., \& Kleinert, J. (2008). Exchange rates and FDI: Goods versus capital market frictions. The World Economy, 31(9), 1185-1207.

Chakrabarti, A. (2001). The determinants of foreign direct investment: Sensitivity analyses of cross country regressions. Kyklos, 54, 89-114.

Chantasasawa, B., Fung, K. C., Lizaka, H., \& Siu, A. (2004). Foreign direct investment in China and East Asia. Paper presented at the Third Annual Conference on China Economic Policy Reform, Stanford Center for International Development (SCID), Stanford University.

Colongeli, N. (2010). The determinants of foreign direct investment: Evidence from Latin America and the Caribbean. Bryant Economic Research Paper, 3(4).

Cross, A. R., \& Tan, H. (2002). The impact of China's WTO accession on Southeast Asian foreign direct investment: Trends and prospects. 28th Annual Conference of EIBA: University of Leeds, UK.

Cuyvers, L., Soeng, R., Plasmans, J., Bulcke, D. V. D. (2011). Determinant of FDI in Cambodia. Journal of Asian Economics, 22(3), 222-234.

Daly, K., \& Tosompark, T. C. (2011). Determinants of foreign direct investment in Thailand. The Impact of the Global Financial Crisis on Emerging Financial Markets Contemporary Studies in Economic and Financial Analysis, 93, 709-718.

Davidson, W. H. (1980). The location of foreign direct investment activity: Country characteristics and experience effects. Journal of International Business Studies, 11, 9-22.

Dunning, J. H. (1981). International production and the multinational enterprise. London: Allen \& Unwin.

Fan, X., \& Dickie, P. M. (2000). The contribution of foreign direct investment to growth and stability: Post crisis ASEAN-5 Review. ASEAN Economic Bulletin, 17, 312-323.

Freeman, N. J., \& Bartels, F. L. (2004). The future of foreign direct investment in Southeast Asia (1sted.). New York: Routledge Curzon. 
Froot, K. A., \& Stein, J. C. (1991). Exchange rates and foreign direct investment: An imperfect capital markets approach. The Quarterly Journal of Economics, 106, 1191-1217.

Helpman, E., \& Krugman, P. R. (1985). Market structure and foreign trade. Cambrige: MIT Press.

Hill, H., \& Jongwanich, J. (2009). Outward foreign direct investment and the financial crisis in developing East Asia. Asian Development Review, 26(2), 1-25.

Hines, J. R. (1996). Altered states: Taxes and the location of foreign direct investment in America. The American Economic Review, 86(5), 1076-1094.

Hines, J. R., \& Rice, E. M. (1994). Fiscal paradise: Foreign tax havens and American business. The Quarterly Journal of Economics, 109(1), 149-182.

Ioannatos, P. E. (2001). The demand determinants of foreign direct investment: Evidence from nonnested hypotheses. In C. C. Paraskevopoulos, T. Georgakopoulos, \& L. Michelis (Eds.), The asymmetric global economy: Growth, investment and public policy (pp. 119-135). Toronto: APF Press.

Jun, K. W., \& Singh, H. (1996). The determinants of foreign direct investment in developing countries. Transnational Corporations, 5, 67-105.

Krugman, P. R., \& Obsfeld, M. (1994). International economic (3rd ed.). New York: Harper Collins.

Krugel, W. (2005). The determinants of foreign direct investment in Africa. Journal of Business and Economics, 1, 49-71.

Lall, S. (2003). Assessing industrial competitiveness: How does Singapore fare? In R. Rajan (Ed.), Sustaining competitiveness in the new global economy: A case study of Singapore. Cheltenham: Edward Elgar.

Lee, B., \& Min, S. (2011). Exchange rates and FDI strategies of multinational enterprises. Pacific-Basin Finance Journal, 19(5), 586-603.

Liu, X., \& Wang, C. (2003). Does foreign direct investment facilitate technological progress evidence from Chinese industries. Research Policy, 32, 945-953.

Liu, X., Song, H., Wei, Y., \& Romilly, P. (1997). Country characteristics and foreign direct investment in China: A panel data analysis. Review of World Economics, 133(2), 313-329.

Liu, Z. (2008). Foreign direct investment and technology spill overs: Theory and evidence. Journal of Development Economics, 85, 176-193. 
Lucas, R. (1993). On the determinants of direct foreign investment: Evidence from East and South Asia. World Development, 21, 391-406.

Lui, F. T. (1985). An equilibrium queuing model of bribery. Journal of Political Economy, 93, 760-781.

Markusen, J. R. (2002). Multinational firms and the theory of international trade. Cambridge: MIT Press.

Moshirian, F. (1997). Foreign direct investment in insurance services in the United States. Journal of Multinational Financial Management, 7, 159-173.

Normaz, W. I. (2009). The determinant of foreign direct investment in ASEAN: A semi-gravity approach. Journal Transition Studies Review, 16(3), 710-722.

Owen, R. F. (1982). Inter-industry determinants of foreign direct investments: A Canadian perspective. In A. M. Rugman (Ed.), New theories of multinational enterprise. London: Croom Helm.

Petrochilas, G. A. (1989). Foreign direct investment and the development process. Aldershot: Avebury

Puah, H., Kueh, J. S. H., \& Lau, E. (2007). The implications of emergence of China towards Asean-5: FDI-GDP perspective. MPRA Paper No. 5219. Universiti Malaysia Sarawak

Rajan, R. (2003a). Implications of the emergence of the PRC as an economic power for ASEAN: Threat, opportunity, or both? (Unpublished report for the Asian Development Bank).

Rajan, R. (2003b). Emergence of China as an economic power: What does it imply for Southeast Asia? Economic and Political Weekly, 38, 2639-2644.

Razafimahefa, I. V., \& Hamori, S. (2007). FDI competitiveness: International competitiveness in Africa. Advanced Studies In Theoretical and Applied Econometrics, 43, 61-70.

Ramasamy, B., \& Yeung, M. (2010). The determinant foreign direct investment in Services. The World Economy, 33(4), 573-596.

Ravenhill, J. (2006). Is China an economic threat to Southeast Asia? Asian Survey, 46(5), 653-674.

Scholes, M. S., \& Wolfson, M. A. (1990). The effects of changes in tax law on corporate reorganization activity. Journal of Business, 63 , 141-164.

Seetanah, B., \& Rojid, S. (2011). The determinants of FDI In Mauritius: A dynamic time series investigation. Journal of Economic and Management Studies, 2(1), 24-41.

Seim, T. L.(2009). FDI and openness: Differences in response across countries. Bergen: Norway. 
Sinani, E., \& Meyer, K. E. (2004). Spillovers of technology transfer from FDI: The case of Estonia. Journal of Comparative Economics, 32, 445-466.

Singhania, M., \& Gupta, A. (2011). Determinants of foreign direct investment in India. Journal of International Trade Law and Policy, 10(1), 64-82.

Srivastava, S., \& Rajan, R. S. (2003). Implications the economic rise of the PRC for ASEAN and India: Trade and foreign direct investment. IPS Working Paper No.14, November, South Asian Studies Programme, National University of Singapore, Singapore.

Swenson, D. L. (1994). The impact of US tax reform on foreign direct investment in the United States. Journal of Public Economics, 54, 243-266.

Thomas, D. E., \& Grosse, R. (2001). Country-of-origin determinants of foreign direct investment in an emerging market: The case of Mexico. Journal of International Management, 7, 59-79.

Tsai, P. (1994). Determinants of foreign direct investment and its impact on economic growth. Journal of Economic Development, 19, 137-163.

Urata, S., \& Kawai, H. (2000). The determinants of the location of foreign direct investment by Japanese small and medium-sized enterprises. Small Business Economics, 15, 79-103.

Wang, Z. Q., \& Swain, N. (1997). Determinants of inflow of foreign direct investment in Hungary and China: Time-series approach. Journal of International Development, 9, 695-726.

Wan, G., \& Xing, Y. (2006). Exchange rates and competition for FDI in Asia. Journal World Economy, 29(4), 419-434.

Wei, Y., \& Liu, X. (2001). Foreign direct investment in China: Determinants and impact. New York: Oxford University Press.

Wheeler, D., \& Mody, A. (1992). International investment location decisions: The case or U.S. firms. Journal of International Economics, 33, 57-76.

Wijeweera, A., \& Mounter, S. (2008). A VAR analysis on the determinant of FDI inflows: The case of Sri Lanka. Applied Econometrics and International Development, 8(1), 189-198.

Wijeweera, A., Brian, D., \& Clark, D. (2009). Corporate tax rates and foreign direct investment in the United States. Applied Economics, 39, 109-117.

Yamin, M., \& Sinkovics, R. R. (2008). Infrastructure or foreign direct investment? An examination of the implications of MNE strategy for economic development. Journal of World Business, 44, 144-157. 
Yang, J. Y. Y., Groenewold, N., \& Tcha, M. (2000). The determinants of foreign direct investment in Australia. The Economic Record, $76,45-54$.

Yudavae, K., Kozlov, K., Melentieva, N., \& Natalia, P. (2003). Does foreign ownership matter? The Russian experience. Economics of Transition, 11(3), 383-409.

Zhang, Z., \& Ow, C. H. (1996). Trade interdependence and direct foreign investment between ASEAN and China. World Development, 24(1), 155-170.

Zhao, H. (2003). Country factor differentials as determinants of FDI flow to China. Thunderbird International Business Review, 45, 149-169.

Zhou, Y., \& Lall, S. (2005). The impact of China's FDI surge on FDI in South-East Asia: Panel data analysis for 1986-2001. Transnational Corporations, 14(1), 41-65.

Zivengwa, T., Mashika, J., Bokosi, F. K., \& Makova, T. (2011). Stock market development and economic growth in Zimbabwe. International Journal of Economics and Finance, 3(5), 140-150. 
IJMS 20 (1), 77-108 (2013)

\section{Appendix 1}

Result of Unit Root Test for Each Variable of Each Country

Table 1

ADF Unit Root Test for Indonesia

\begin{tabular}{lll}
\hline Variable & Level & First Difference \\
\hline LFDI & $-2.82571^{*}$ & \\
LPCRGDP & -0.142033 & $-5.44451^{* * *}$ \\
LRINT & $-4.67205^{* * *}$ & \\
LLABOR & -1.46473 & $-5.33284^{* * *}$ \\
LOPENESS & -2.34915 & $-6.38138^{* * *}$ \\
LREXC & -2.10273 & $-6.2469^{* * *}$ \\
LTAX & $-4.4288^{* * *}$ & \\
CHINA (Dummy) & -0.64807 & $-5.38517^{* * *}$ \\
\hline
\end{tabular}

Note. ${ }^{* * *},{ }^{* *}$, and ${ }^{*}$ denote significant at $1 \%, 5 \%$, and $10 \%$ confidence level respectively.

Table 2

ADF Unit Root Test for Singapore

\begin{tabular}{lll}
\hline Variable & Level & First Difference \\
\hline LFDI & -1.82242 & $-6.30633^{* * *}$ \\
LPCRGDP & -0.045487 & $-4.74308^{* * *}$ \\
LINT & $-5.34349^{* * *}$ & \\
LLABOR & -0.91518 & $-4.57406^{* *}$ \\
LOPENESS & $-2.84545^{*}$ & \\
LREXC & -1.34981 & $-4.11106^{* * *}$ \\
LTAX & -0.408676 & $-6.48707^{* * *}$ \\
CHINA (Dummy) & -0.64807 & $-5.38517^{* * *}$ \\
\hline
\end{tabular}

Note. ${ }^{* *},{ }^{* *}$, and ${ }^{*}$ denote significant at $1 \%, 5 \%$, and $10 \%$ confidence level respectively. 
IJMS 20 (1), 77-108 (2013)

Table 3

ADF Unit Root Test for Malaysia

\begin{tabular}{lll}
\hline Variable & Level & First Difference \\
\hline LFDI & -2.36719 & $-7.49436^{* * *}$ \\
LPCRGDP & -0.045487 & $-4.74308^{* * *}$ \\
LINT & $-3.47897^{* *}$ & \\
LLABOR & -1.53323 & $-3.52396^{* *}$ \\
LOPENESS & -1.24306 & $-3.60689^{* *}$ \\
LREXC & -1.84538 & $-4.2068^{* * *}$ \\
LTAX & -1.50461 & $-6.39442^{* * *}$ \\
CHINA (Dummy) & -0.64807 & $-5.38517^{* * *}$ \\
\hline
\end{tabular}

Note. ${ }^{* * *}, * *$, and $\mathrm{d}^{*}$ denote significant at $1 \%, 5 \%$, and $10 \%$ confidence level respectively.

Table 4

ADF Unit Root Test for Thailand

\begin{tabular}{lll}
\hline Variable & Level & First Difference \\
\hline LFDI & -1.556 & $-5.48547^{* * *}$ \\
LPCRGDP & -0.55794 & $-3.25191^{* *}$ \\
LINT & -1.95517 & $-6.18853^{* * *}$ \\
LLABOR & -0.60952 & $-4.02035^{* * *}$ \\
LOPENESS & -0.49732 & $-5.1145^{* * *}$ \\
LREXC & -2.13447 & $-6.08005^{* * *}$ \\
LTAX & $-4.4288^{* * *}$ & \\
CHINA (Dummy) & -0.64807 & $-5.38517^{* * *}$ \\
\hline
\end{tabular}

Note. ${ }^{* * *},{ }^{* *}$, and ${ }^{*}$ denote significant at $1 \%, 5 \%$, and $10 \%$ confidence level respectively. 
IJMS 20 (1), 77-108 (2013)

Table 5

ADF Unit Root Test for Philippines

\begin{tabular}{lcc}
\hline Variable & Level & First Difference \\
\hline LFDI & $-23.3634^{* * *}$ & \\
LPCRGDP & -0.602325 & $-3.86413^{* * *}$ \\
LINT & $-0.560515^{* * *}$ & \\
LLABOR & $-3.26935^{* *}$ & \\
LOPENESS & -1.7373 & $-2.70671^{*}$ \\
LREXC & $-2.67969^{*}$ & \\
LTAX & -1.445576 & $-5.94103^{* * *}$ \\
CHINA (Dummy) & -0.64807 & $-5.38517^{* * *}$ \\
\hline
\end{tabular}

Note. ${ }^{* *},{ }^{* *}$, and ${ }^{*}$ denote significant at $1 \%, 5 \%$, and $10 \%$ confidence level respectively. 
IJMS 20 (1), 77-108 (2013)
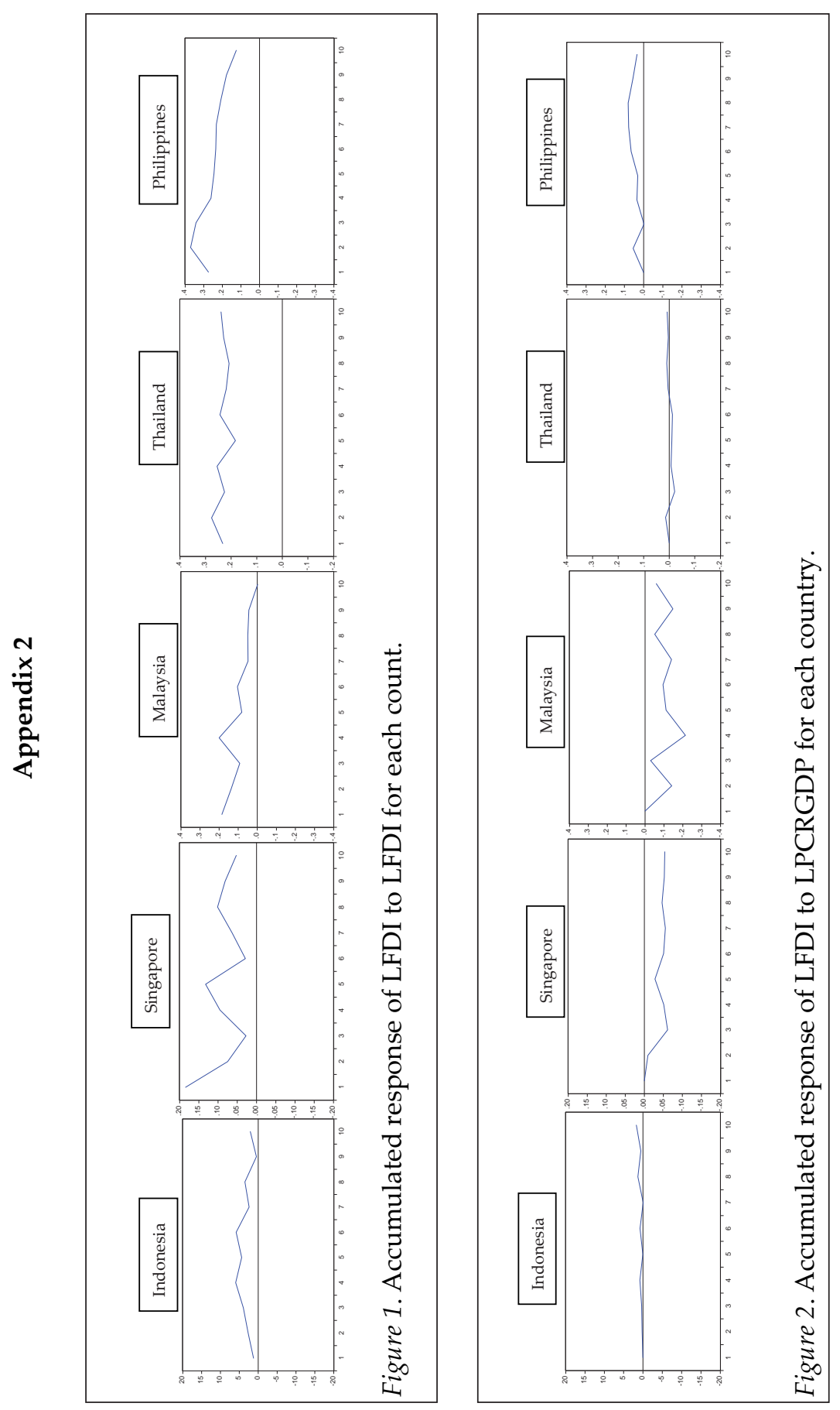
IJMS 20 (1), 77-108 (2013)
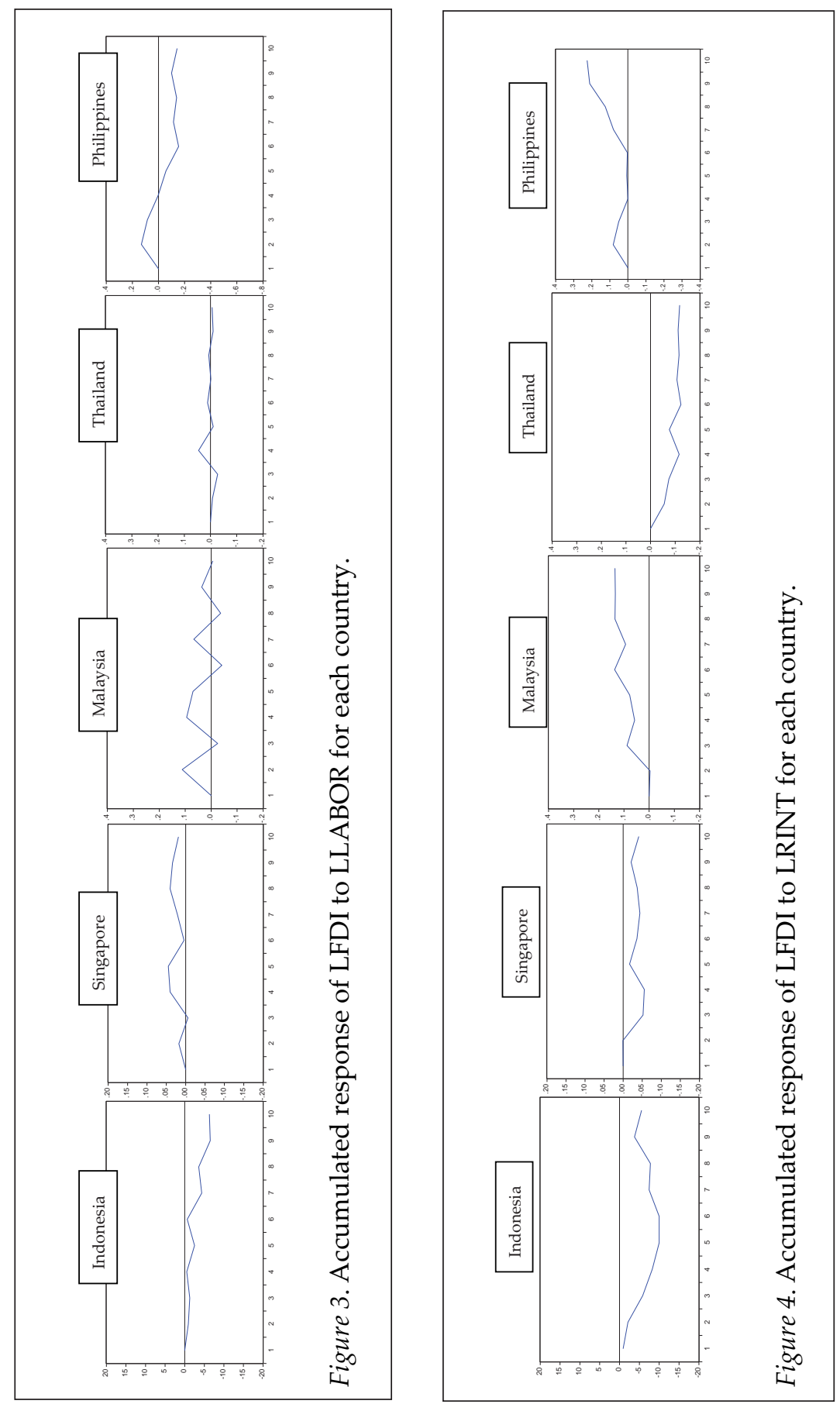
IJMS 20 (1), 77-108 (2013)
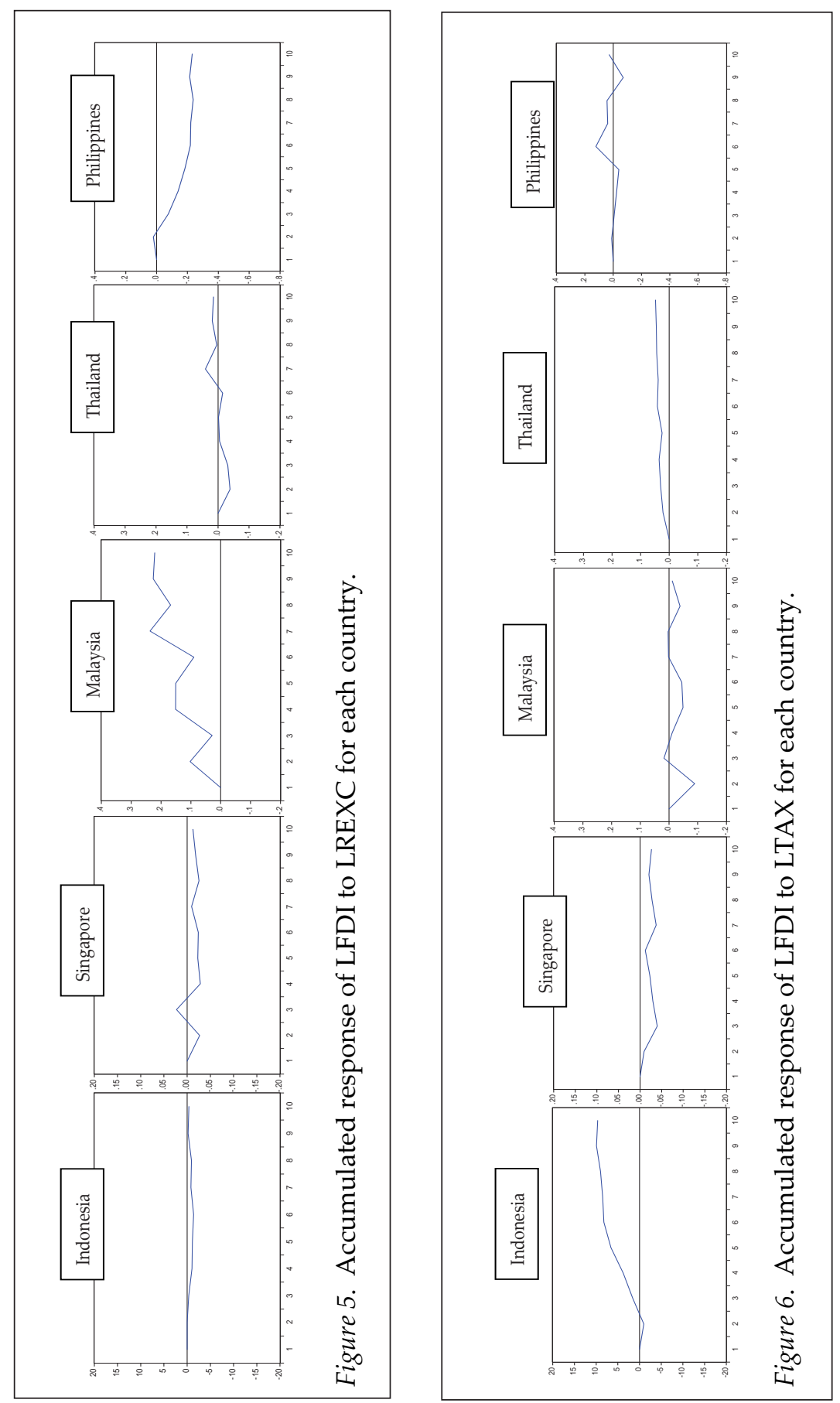
IJMS 20 (1), 77-108 (2013)
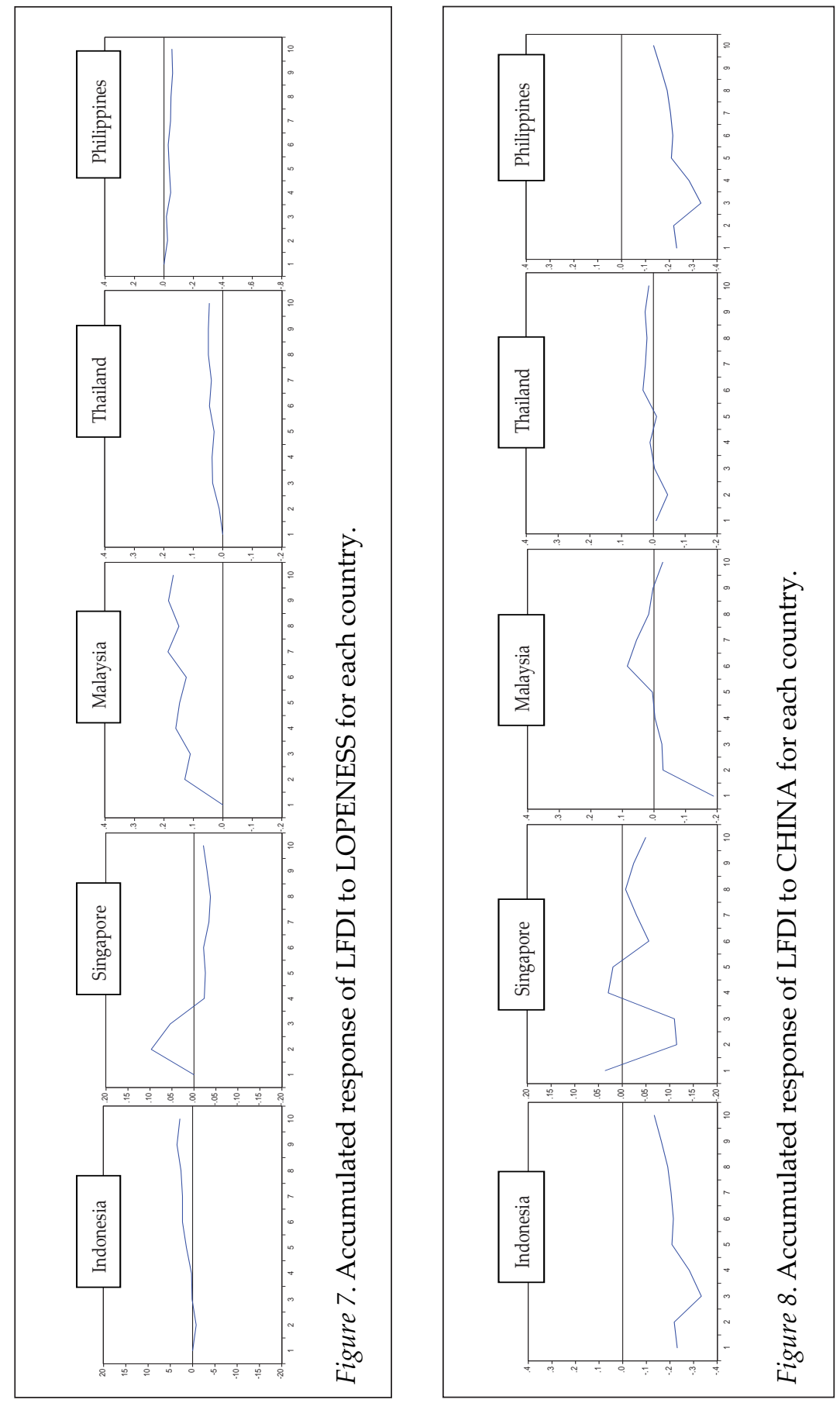